The author reported no conflicts of interest.

The Journal policy requires editors and reviewers to disclose conflicts of interest and to decline handling or reviewing manuscripts for which they may have a conflict of interest. The editors and reviewers of this article have no conflicts of interest.

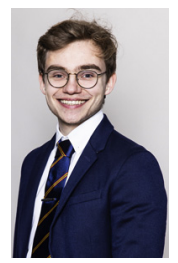

\section{CENTRALIZATION AND \\ REGIONALIZATION OF \\ CONGENITAL HEART \\ SURGERY IN A GLOBALIZED \\ WORLD \\ To the Editor:}

Congenital heart surgery is complex and requires dedicated services to optimize surgeons' skills and patient outcomes. Centralization and regionalization of services enables a pooling of surgical volume by centers and surgeons, whilst trying to limit geographic barriers for patients as a result of such decisions. Backer ${ }^{1}$ illustrates that regionalization enables the pursuit of excellence in congenital heart surgery using the example of Sweden's shift from 4 to 2 centers in 1992.

The question of regionalization often becomes one of revenue, pride, and/or politics. In the United States, the vast variety of hospital networks, insurance schemes, and high direct costs drive incentives to maintain specialized services. In market-based health systems, resourceintensive health services such as congenital heart surgery contribute greatly to hospital revenue whilst highlighting how advanced and comprehensive centers are-even when other centers are just down the street. It is no surprise that a country like the United States could thrive with one-third of the current number of hospitals providing congenital heart surgery. ${ }^{2}$

In Europe, the decision to regionalize has generally been more straightforward-and for good reason: Most European countries have Beveridge (tax-based national health services) or Bismarck health systems (health insurance through payroll taxes) in which universal health coverage is provided and health system efficiency is prioritized. As a result, proportionally fewer centers cover entire countries. With higher volume per center per population unit, they are

\footnotetext{
The Editor welcomes submissions for possible publication in the Letters to the Editor section that consist of commentary on an article published in the Journal or other relevant issues. Authors should: • Include no more than 500 words of text, three authors, and five references. • Type with double-spacing. • See http://jtcs.ctsnetjournals.org/ misc/ifora.shtml for detailed submission instructions. • Submit the letter electronically via jtcvs.editorialmanager.com. Letters commenting on an article published in the JTCVS will be considered if they are received within 6 weeks of the time the article was published. Authors of the article being commented on will be given an opportunity of offer a timely response ( 2 weeks) to the letter. Authors of letters will be notified that the letter has been received. Unpublished letters cannot be returned.
}

more able to promote centers' efficiency, reduce health system costs, and ensure specialized health workers across the care continuum. However, the result of regionalization is more than mere efficiency, volume, and costs, it is also outcomes. Excess mortality for children living with congenital heart defects worldwide is high, even in various high-income countries such as the United States. It deserves more attention in the context of the field's pursuit of excellence.

With new cardiac surgical centers being established in low- and middle-income countries, a similar risk ensues: Because these countries typically have public, private, and even nonprofit health sectors, the parallel establishment of pediatric cardiac surgical services without centralization (eg, through public-private partnerships) limits the ability to promote expansion of centers, services, volume, and outcomes. ${ }^{4}$ The current availability of pediatric cardiac surgeons in low- and middle-income countries is scant compared with high-income countries, but quality cannot be foregone in the race for increased quantity and early fragmentation. ${ }^{5}$ Simultaneously developing multiple, nearby, low-volume centers may not be sustainable in terms of capacity, finances, and outcomes due to high individual procedure costs and the need for comprehensive follow-up care. In line with this, existing centers could rather be scaled to become high(er)-volume centers for a given country and even neighboring countries, potentially serving as the center of excellence in the region.

The drive for cardiac centers to provide congenital heart surgery, which occurs even at the cost of volume and outcomes, requires a paradigm shift to thoughtful regionalization of pediatric cardiac surgical care in all countries to ensure the best possible care for patients living with congenital heart defects.

Dominique Vervoort, MD
Johns Hopkins University Bloomberg School of Public
Health
Baltimore, $M d$

\section{References}

1. Backer CL. Commentary: regionalization $=$ excellence. J Thorac Cardiovasc Surg. September 1, 2020 [Epub ahead of print].

2. Welke KF, Pasquali SK, Lin P, Backer CL, Overman DM, Romano JC, et al A theoretical model for delivery of congenital heart surgery in the United States. Ann Thorac Surg. August 26, 2020 [Epub ahead of print].

3. Vervoort D, Cardarelli M. The global unmet need of congenital cardiac care: a quantitative analysis of the global burden of disease. Cardiol Young. August 20, 2020 [Epub ahead of print].

4. Vervoort D. When a child's surgery goes wrong. Available at: https://www nytimes.com/2019/06/04/opinion/letters/childen-surgery-unc-hospital.html. Accessed September 15, 2020.

5. Vervoort D, Meuris B, Meyns B, Verbrugghe P. Global cardiac surgery: access to cardiac surgical care around the world. J Thorac Cardiovasc Surg. 2020;159; 987-96.e6.

https://doi.org/10.1016/j.jtcvs.2020.09.014 